\title{
The effects of low glucosinolate rape seed varieties Leo and Mar on the performance of Starbro and Vedetta broiler chickens
}

\author{
Stefania Kinal, Zofia Fritz and Alina Schleicher
}

\author{
Department of Animal Nutrition and Feed Sciences, \\ Wroclaw Agricultural liniversity \\ Norwida 25/27, 50-375 Wroclaw, Poland
}

(Received 18 April 1994; accepted 12 May 1994)

\begin{abstract}
The experiment was carried out on 1440 broiler chickens assigned to 6 groups and lasted 8 weeks. The analyzed factors were brecding lines (Starbro and Vedetta) and rape seed varieties (Leo and Mar). The chickens in the experimental groups were fed $5 \%$ rape seed in their diets. At the age of 8 weeks the Starbro chickens that were given both rape varieties showed higher $(P \leqslant 0.01)$ body weight gains and consumed less feed than Vedetta chickens. The tatter line, however, had a much better carcass yield $(P \leqslant 0.01)$ than Starbro. The thyroids of the experimental chickens from both lines were about $40 \%$ heavier than of controls. Feeding both varieties of rape seeds in the diets increased the femoral calcium content in both lines.
\end{abstract}

KEY WORDS: broiler chickens (Starbro and Vedetta), low glucosinolate rape seeds

\section{INTRODUCTION}

The introduction of low glucosinolate rape varieties has led to increased interest in their possible role in feeding poultry (Bougon et al., 1988; Chrappa et al., 1991; Hanczakowski and Fraś, 1983; Korelski and Ryś, 1987; Lee et al., 1991; Sim and Nwokolo, 1987). The nutritive value of rape seed is determined by its protein, fat and fibre contents as well as by the level of glucosinolates which, in the new varieties, usually does not exceed $25 \mu \mathrm{M} / \mathrm{g}$ of fat-free dry matter (Buraczewska et al., 1989; Kinal et al., 1990; Korol et al., 1992; Matyka et al., 1992; Smulikowska et al., 1990).

In the experiment reported in this paper, rape seeds of the low glucosinolate varieties, Leo and Mar, were included in the diets of Starbro and Vedetta broiler chickens to test their effect on performance. 


\section{MATERIAL AND METHODS}

The experiment was conducted on 1440 broiler chicks randomly assigned to 6 groups, each with 4 replicates. The factors differing the groups were: chicken line (Starbro or Vedetta) and rape seed variety (Leo or Mar). The birds were kept on deep litter under standard conditions and fed according to two feeding schedules: 0-3 weeks of age starter, 4-8 weeks finisher diets. The birds in the groups I and II received the same control diet (Table 1). The chickens in the experimental groups were given feeds with a $5 \%$ content of ground rape seeds. The groups were defined as follows:
1 - control, Starbro
II - control, Vedetta
III - Leo rape seeds, $5 \%$, Starbro
IV - Leo rape seeds, $5 \%$, Vedetta
V - Mar rape seeds, $5 \%$, Starbro
VI - Mar rape seeds, 5\%, Vedetta

TABLE 1

Composition of feed mixtures. $\%$

\begin{tabular}{|c|c|c|c|c|}
\hline \multirow{3}{*}{ Ingredients } & \multicolumn{4}{|c|}{ Feed mixlures } \\
\hline & \multicolumn{2}{|c|}{ Starter } & \multicolumn{2}{|c|}{ Finisher } \\
\hline & control & Lco and Mar & control & Leo and Mar \\
\hline Maize & 25.0 & 25.0 & 30.0 & 30.0 \\
\hline Wheat & 32.6 & 27.6 & 34.2 & 29.2 \\
\hline Soyabean oil meal. $4 \%$ fat & 20.0 & 20.0 & 10.8 & 10.8 \\
\hline Triticale & 7.0 & 7.0 & 15.0 & 15.0 \\
\hline Rape seeds Leo or Mar & - & 5.0 & - & 5.0 \\
\hline Meat meal & 10.0 & 10.0 & 4.0 & 4.0 \\
\hline Barley germs & 2.0 & 2.0 & 2.0 & 2.0 \\
\hline Limestone & 1.9 & 1.9 & 1.1 & 1.1 \\
\hline Dicalcium phosphate & - & - & 1.3 & 1.3 \\
\hline Cerbiogalli (probiotic) & 0.2 & 0.2 & 0.2 & 0.2 \\
\hline $\mathrm{NaCl}$ & 0.3 & 0.3 & 0.4 & 0.4 \\
\hline $\begin{array}{l}\text { Mineral - vitamin } \\
\text { premix DKA }\end{array}$ & 1.0 & 1.0 & 1.0 & 1.0 \\
\hline Chemical compisition & & & & \\
\hline Crude protein $\%$ & 21.26 & 21.68 & 19.00 & 19.44 \\
\hline Crude fibre $\%$ & 3.47 & 3.62 & 3.26 & 3.10 \\
\hline Fat $\quad \%$ & 2.82 & 4.68 & 2.97 & 4.82 \\
\hline $\mathrm{AME}_{\mathrm{N}}{ }^{1} \quad \mathrm{MJ} / \mathrm{kg}$ & 12.28 & 12.60 & 12.44 & 12.76 \\
\hline $\mathrm{Ca}$ & 9.85 & 9.56 & 7.09 & 7.24 \\
\hline $\mathrm{g} / \mathrm{kg}$ & 7.46 & 7.32 & 7.64 & 7.50 \\
\hline
\end{tabular}

' calculated according to Nutrient Requirements of Poultry (1991) 
Leo and Mar seeds contained 19.4 and $19.8 \%$ crude protein, 9.8 and $10.2 \%$ crude fibre and 39.7 and $41.0 \%$ crude fat, respectively. According to the certificate issued by the Seed Qualification Station in Zielona Gora, the Leo seeds bclonged to the elite class and contained $0.1 \%$ erucic acid and $4 \mu \mathrm{M}$ glucosinolates in $1 \mathrm{~g}$ fat-free DM. Mar rape seeds were classified as original and contained $0.2 \%$ erucic acid and $16 \mu \mathrm{M}$ glucosinolates, respectively.

The birds were weighed after 3 and 8 weeks and their weight gain and feed consumption per $\mathrm{kg}$ gain were determined. After completion of the experiment, 8 birds with live body weight (LBW) close to the average for group ( 4 males and 4 females) were selected, slaughtered and simplified dissection of the carcasses was carried out. Dressing performance was determined, as were the percentage of breast muscles, liver, giblets and abdominal fat in the dressed carcass. The weight of the isolated thyroid glands is expressed in $\mathrm{mg} / 100 \mathrm{~g} \mathrm{LBW}$. In order to better determine the quality of the meat in the breast muscles, their dry matter content and water binding capacity were determined. The femurs were removed from the carcasses, defatted with ethyl ether, after which their mass and volume were determined. After mineralization, the calcium content of the femurs was determined by atomic absorption spectrometry using an ASO apparatus.

The results were subjected to two-way analysis of variance. The means were compared by the Duncan test.

\section{RESULTS AND DISCUSSION}

Distinct differences in performance among groups were seen (Table 2). Those groups of birds receiving both rape cultivars had 4 to $7 \%$ higher body weight gains (BWG) at the age of 3 weeks than the control groups $(P \leqslant 0.01)$. During this period, the Starbro chickens in groups III and V had the lowest feed conversion ratio $(\mathrm{FCR})(\mathrm{P} \leqslant 0.05)$ and they also had greater $B W G$ than Vedetta chickens.

At the age of 8 weeks, chickens from both Vedetta and Starbro control groups had similar mean body weights $(2.0 \mathrm{~kg}$ on average) as did the Starbro birds in groups III and V. The chickens from the Vedetta line in groups IV and VI were lighter and this difference was significant $(P \leqslant 0.01)$. The Starbro chickens continued to utilize feed better during this period, but this trend was not confirmed statistically.

Mortality during the experiment averaged of 2.8 in control group $I$ and $5.5 \%$ in group II and can be considered within normal range.

The dressing percentage of Vedetta chickens was higher than that of Starbro $(P \leqslant 0.01)$. Vedetta carcasses had a higher proportion of breast muscles than Starbro, especially in experimental groups IV and VI that were given the feeds containing rape seeds $(P \leqslant 0.01)$. The percentages of the liver and edible giblets in dressed carcasses were similar in all groups. The amount of abdominal fat in the 
TABLE 2

Performance of broilers

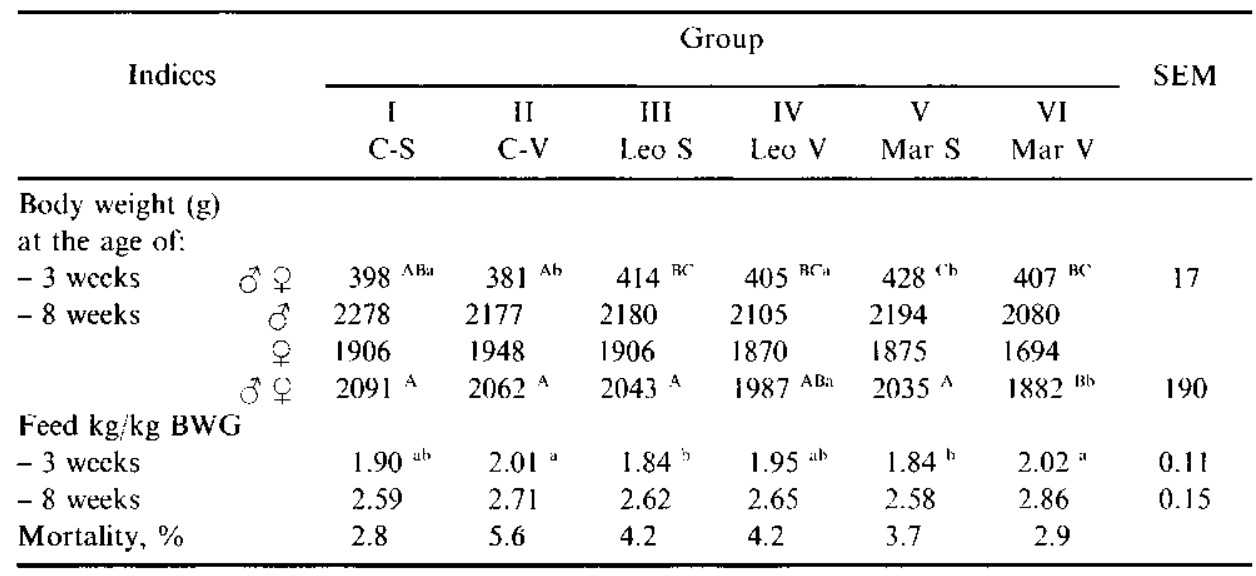

Values with the same superscript or without superscript within a row are not statistically different at $\mathrm{a}, \mathrm{b}, \mathrm{c}=\mathrm{P} \leqslant 0.05 \quad \mathrm{~A}, \mathrm{~B}, \mathrm{C}=\mathrm{P} \leqslant 0.01$

$\mathrm{C}$ - control. S - Starbro line, $\mathrm{V}$ - Vedetta line

TABLE 3

Slaughter results

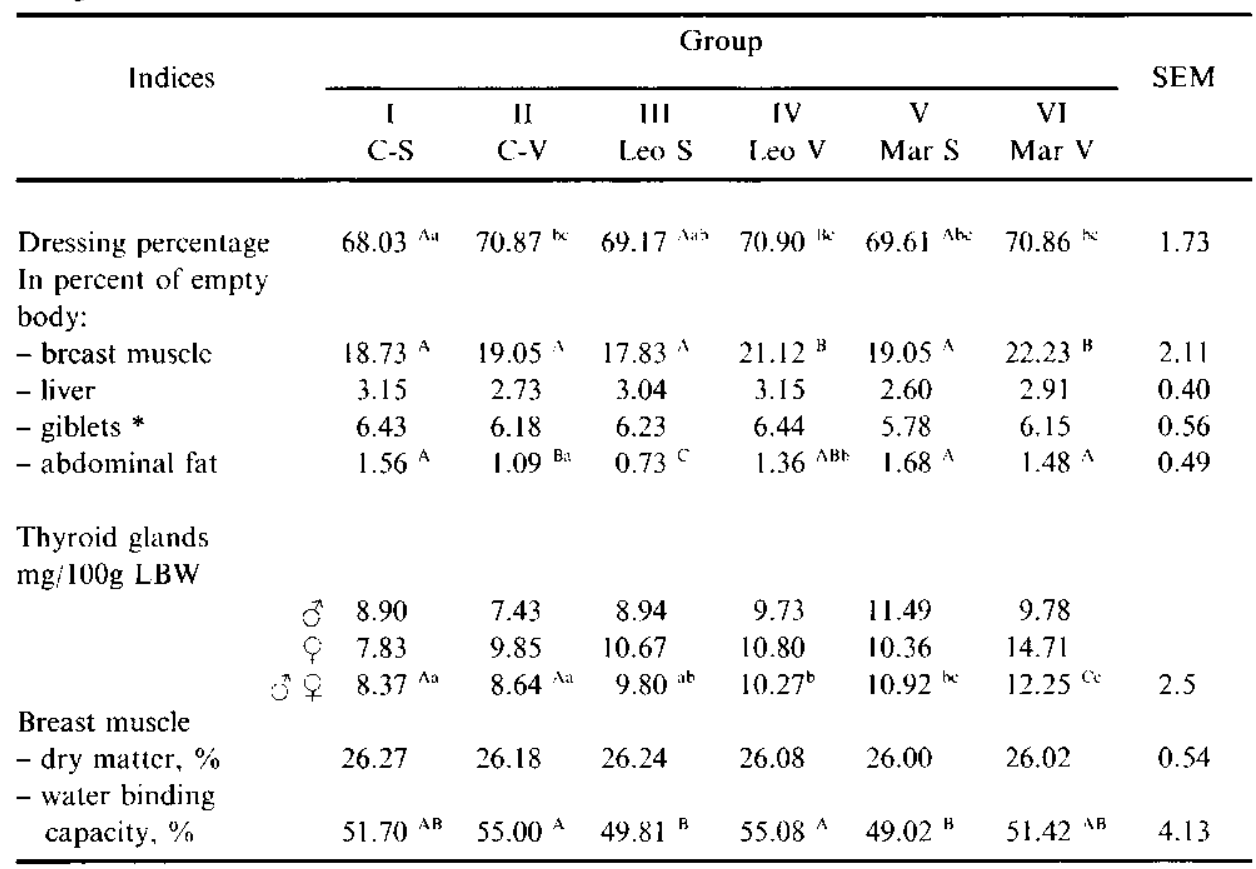

a, b, A, B - as in the Table 2

C, S, V - as in the Table 2

* - liver, gizzard and heart 
carcasses was rather low and ranged from 0.37 (group III) to $1.68 \%$ (group V). When considering the high degree of individual variability in terms of this factor and its small share in body composition, the statistical significance of the changes can not, in our opinion, be interpreted in an unequivocal manner.

As could have been expected, the weight of the thyroids in both lines receiving rape seeds was significantly higher than in the control birds. A relationship between the weight of the thyroid and the glucosinolate content of rape seeds was found. At $4 \mu \mathrm{M} / \mathrm{g}$ fat-free DM (Leo), the thyroids weighed 9.8 to $10.1 \mathrm{mg} / 100$ $\mathrm{g}$ body wcight, while at $16 \mu \mathrm{M} / \mathrm{g}$ fat-free DM (Mar), 10.9 and $12.2 \mathrm{mg} / 100 \mathrm{~g}$ body weight, respectively. Similar relationships were shown by Kinal et al. (1990) and Smulikowska et al. (1990). It should be underlined that on the same dict a tendency for more marked thyroid hypertrophy in Vedetta chickens was visible. The thyroids of females were usually heavier when expressed in $\mathrm{mg} / 100$ g body weight than in males, which agrees with the results obtained by Kinal et al. (1990).

The DM content of breast muscles did not show any significant differences among groups, however, the water binding capacity of Vedetta meat in groups II and IV was significantly higher $(\mathrm{P} \leqslant 0.01)$ than in Starbro.

Bone dry matter contents, their specific density as well as ash contents were similar in all groups (Table 3 ). The calcium content in the femurs of chickens fed rape seed containing diets was higher, and the difference in relation to the control groups was confirmed statistically $(P \leqslant 0.01)$ for group $V$ and $(P \leqslant 0.05)$ for group IV. This is in disagreement with the results of other authors who showed that in poultry the availability of $\mathrm{Ca}$ and bone mineralization declined when the birds are given feeds containing rape seeds (Leeson et al., 1987; Nwokolo and Bragg, 1977; Zgłobica and Wẹżyk, 1991).

TABLE 4

Analysis of tibia

\begin{tabular}{|c|c|c|c|c|c|c|c|}
\hline \multirow{2}{*}{ Indices } & \multicolumn{6}{|c|}{ Group } & \multirow{2}{*}{ SEM } \\
\hline & $\begin{array}{c}\mathrm{I} \\
\mathrm{C}-\mathrm{S}\end{array}$ & $\begin{array}{c}\text { II } \\
C \cdot V\end{array}$ & $\begin{array}{c}\text { IlI } \\
\text { Ico S }\end{array}$ & $\begin{array}{c}\text { IV } \\
\text { I.co V }\end{array}$ & $\begin{array}{c}\mathrm{V} \\
\text { Mar S }\end{array}$ & $\begin{array}{c}\text { VI } \\
\text { Mar V }\end{array}$ & \\
\hline Dry matter, $\%$ & 88.82 & 87.91 & 88.34 & 88.54 & 89.26 & 87.97 & 1.13 \\
\hline Weight, $\%$ of $\mathrm{LBW}$ & 0.86 & 0.72 & 0.81 & 0.77 & 0.80 & 0.74 & 0.11 \\
\hline Density, $\mathrm{g} / \mathrm{cm}^{3}$ & 1.21 & 1.22 & 1.23 & 1.19 & 1.18 & 1.24 & 0.10 \\
\hline Crude ash, $\%$ & 37.2 & 39.5 & 38.7 & 38.8 & 39.1 & 40.5 & 3.4 \\
\hline $\mathrm{Ca}, \%$ & $26.8^{\mathrm{Ai1}}$ & $28.0^{32}$ & $28.1^{15 \mathrm{~b}}$ & $29.1^{\mathrm{buc}}$ & $30.1^{\mathrm{BC}}$ & $28.3^{\text {ib }}$ & 2.0 \\
\hline
\end{tabular}

a, b; A, B - as in the Table 2

C. S, V-as in the Table 2 


\section{CONCLUSIONS}

Chickens fed diets with a $5 \%$ content of Leo or Mar variety rape seeds showed greater weight gains during the first period of breeding than birds in control groups $(P \leqslant 0.01)$.

Under the same conditions of feeding, final performance indices were better in Starbro chickens than in those from the Vedetta line.

The femoral calcium content was higher in those birds that were fed diets containing rape secds.

\section{REFTRENCES}

Bougon M., Boixel J.L., Tomassone R., 1988. Intêret du tourteau de colza 00 dépélliculé chè le poulet. Bull. d'Inf. St. Experiment. d'Aviculture de Ploufragan 28, (4), 155-162

Buraczewska L.. Buraczewski S., Pastuszewska B., Grala W. 1989. Composition and nutritive value of rapeseeds 00 and rapeseed oil meal as procein and essential amino acids supplement for feeds (in Polish). Zesz. probl. IHAR Radzików, Results of investigation 1988 year. 363-379

Chrappa V., Stráżnicka H., Abelova II., Sabo V., 1991. Effect of feeding rape seeds 00 on performance of broilers (in Czech). Živocisna Výroba 36, 437-448

Hanczakowski P., Fraś B., 1983. The nutritive value of full-fat seeds and commercial meal from low - glucosinolate low- erucic acid and traditional varieties of rape (in Polish). Rocz. Nauk. Zool. 10(1). 91-99

Kinal S., Fritz Z., Jarosz L., Schleicher $\Lambda$., 1990. Rape seeds partly defatted and rapeseed oil meal from var. Jantar in the feeding of broilers (in Polish). Roc\%. Nauk. Zoot.. Monogr. Ro\%pr. 28, $251-260$

Koreleski J., Ryś R., 1987. Preliminary investigations of the utilisation of full-fat rape seeds from double zero varieties in the feeding of broilers (in Polish). Biul. inf. Przem. Pasz. 26, (3), 24-30

Korol W., Jaśkicwic\% T., Bogusz G., 1992. Evaluation of feeding value of oilseed rape currently cultivated in Poland (in Polish). Zes $\%$ probl. ItIAR Radrików, Rośliny oleiste 14 (II), 406-411

Lee K.I., Olomu I.M., Sim I.S., 1991. Live performance, carcass yicld, protein and energy retention of broiler chickens fed canola and flax full-fat seeds and the restored mixtures of meal and oil. Can. J. Anim. Sci. 71, 897.903

Leeson S., Atteh J.D.. Summers J.D.. 1987. Fffect of increasing dietary levels of full-fat canola on performance, nutrient retention and bone mineralization. Poultry Sci. 66, 875-880

Matyka S., Jaśkicwicz T., Bogusz G.. Korol W., 1992. A note on the chemical composition of low-glucosinolate rape seed produced in North-Eastern Poland. J. Anim. Feed. Sci. 1, 177-182

Nutrient Requirements of Poultry (in Polish), 1991. Publ. of 'The Kiclanowski Institute of Animal Physiology and Nutrition, Jabłonna, Poland

Nwokolo E.N., Bragg D.B., 1977. Influence of phytic acid and crude fibre on the availability of minerals from four protein supplements in growing chicks. Can. J. Anim. Sci. 57, 475.477

Sim J.S. Nwokolo E.N., 1987. Barley and full-fat canola seeds in broiler dicts. Agric. Forestry Bull., Univ. Alberta. Special Issuc, 35-38

Smulikowska S., Chibowska M., Wiśniewska J., 1990. Effects of low glucosinolate rape seed - raw, pressed or extracted on performance, thyroid status and fatty acid profile of broiler chicken. In: Proceedings of 8th European Poultry Conference, 25-28 June, Barcelona. 348-351 
Zglobica $\Lambda$., Weczyk S., 1991. Effect of greasy rations containing raw rape sceds on the growing chicken performance and egg production during lay period (in Polish). Rocz. Nauk. Zoot., Monogr. Rozpr. 29, 217-227

\section{STRES7.C7TINIF:}

Nasiona rzepaku odmian niskoglukozynolanowych, Leo i Mar, jako skladnik mieszanek dla kurcząt brojlerów Starbro i Vedetta

Badania prowadzono przez 8 tygodni na 1440 kurczętach brojlerach przydziclonych do 6 grup doświadczalnych. Czynnikami badanymi były linic kurcząt (Starbro i Vedetta) i odmiany rzepaku (Leo i Mar). Kurczętom grup doświadcralnych podawano w mieszankach $5 \%$ nasion rzepaku. W wieku 8 tygodni kurçęta linii Starbro, otrzymujące nasiona obydwóch odmian rzepaku, miały większe $(\mathrm{P} \leqslant 0.01)$ przyrosty masy ciała i zuzywały mniej paszy niż ptaki linii Vedetta. Wyráznie $(\mathrm{P} \leqslant 0.01)$ lepsze wyniki poubojowe miały ptaki linii Vedetta w porównaniu ze Starbro. Masa tarezyc kurcząt $z$ obydwóch grup doświadczalnych była o ok. $40 \%$ większa w porównaniu z ptakami $z$ grupy kontrolnej. Podawanie w paszy nasion rzepaku obydwóch odmian podwy'ssyło poziom wapnia w kościach udowych kurcząt. 